\title{
Identification of Drilling of Biocompatible Materials Based on Titanium
}

Dana Stancekova ${ }^{1}$, Jan Semcer ${ }^{1}$, Anna Rudawska ${ }^{2}$, Robert Cep ${ }^{3}$

${ }^{1}$ University of Zilina, Faculty of Mechanical Engineering, Univerzitna 1, 010 26, Zilina, Slovak Republic

dana.stancekova@fstroj.uniza.sk, jan.semcer@fstroj.uniza.sk,

${ }^{2}$ Lublin University of Technology, Faculty of Mechanical Engineering, ul. Nadbystrzycka 36, 20-618 Lublin, Poland

a.rudawska@pollub.pl

${ }^{3}$ VSB -TU Ostrava, Faculty of Mechanical Engineering, 17. listopadu 15/2172, 70833 Ostrava, Czech Republic robert.cep@vsb.cz

At present commonly used conventional materials are substituted by materials of better mechanical qualities. For example highly alloyed steels with chromium, cobalt and nickel alloys, titanium and titanium alloys belong to this group. Titanium and its alloys also belong to the group of hardly machinable materials thanks to its good chemical and physical properties, such as high strength, high corrosion resistance, low density, deformation resistance at high temperature and at the same time low thermal conductivity that unfavourably affects the process of machining. Despite its more complicated machining, titanium together with its alloys are widely used in the aerospace, aviation and automotive industries and, last but not least, in biomedicine. Biologically compatible materials are used for production of implants in medicine from comercially pure titanium TiGr2, TiGr5, nanostructured commercially pure titanium nTI and titanium alloys TiNbTa. As there is a need to produce still smaller and more complex implant with extraordinary accuracies, there arises a strong necessity to understand the process of their machining. We have already published experimentally gained knowledge on turning and milling of stated materials. In this paper we aim to inform about machinability of these materials in drilling.

Keywords: titanium, a biocompatible material, drilling, torque

\section{Acknowledgement}

The article was funded by the grant project VEGA 1/0773/12 - "Implementation of technical ceramic material research to increase the innovation of hybrid products".

\section{References}

[1] ŠEMCER, J., CZÁN, A., ŠTEKLÁČ, D. (2009). Research of bioactive and biocompatibile materials from the point of implementation methods and machining conditions. In. ERIN 2009.

[2] PETRŮ, J., ZLÁMAL, T., ČEP, R., PAGÁČ , M., GREPL, M. (2013). Influence of strengthening effect on machinability of the welded inconel 625 and of the wrought Inconel 625. In. IMETI 2013 - 6th International MultiConference on Engineering and Technological Innovation, Proceedings, pp.155 - 159.

[3] ČEP, R., JANÁSEK, A., PETRŮ, J., SADÍLEK, M., MOHYLA, P., VALÍČEK, J., HARNIČÁROVÁ, M., CZÁN, A. (2014). Surface roughness after machining and influence of feed rate on process. In. Key Engineering Materials, Vol. 581, pp. 341 - 347.

[4] MRAZOVA, M., STANCEKOVA, D., SEMCER, J. (2011) Comparasion of machinability of biocompatible materials used in medicine for dental implants. In. DAAAM, pp. 1115-1116.

[5] CZÁN, A., SAJGALÍK, M., HOLUBJAK, J., KOURIL, K. (2013) Studying of cutting zone when finishing titanium alloy by application of multifunction measuring syste. In. Manufacturing Technology, Vol. 13, No. 4, pp. 428-431.

[6] RUDAWSKA, A., KUCZMASZEWSKI, J. (2006). Surface free energy of zinc coating after finishing treatment. In. Materials Science- Poland, Vol. 24, Issue 4, pp. 975-981.

[7] SADÍLEK, M., KRATOCHVÍL, J., PETRŮ, J.,CEP, R., ZLÁMAL, T., STANČEKOVÁ, D. (2014) Cutting tool wear monitoring with the use of impedance layers. In. Tehnicki Vjesnik, volume 21, 3/2014, pp. $639-644$.

[8] BAS, G., STOEV, L. DURAKBASA, N.M. (2015). Assessment o. The production quality in machining by integrating a system of high precision measurement. In. Energy Procedia, Vol. 100, Issue C, pp. 1616-1624.

[9] SKOČOVSKÝ, P. - BOKŮVKA, O. - KONEČNÁ, R. - TILLOVÁ, E. (2006). Náuka o materiáli pre odbory strojnícke. Žilina: EDIS, 349 p.

[10]DUPLÁK, J., ZAJAC, J., HATALA, M., MITAL', D., KORMOŠ, M. (2014). Study of surface quality after turning of steel AISI 304 . In. Manufacturing Technology, Vol. 14, Issue 4, pp. 527 - 532. 
[11]MARAČEKOVÁ, M., ZVONČAN, M., GÖRÖG, A. (2012). Effect of clamping pressure on parts inaccuracy in turning. In Tehnički Vjesnik - Technical Gazette. Vol. 19, No. 3, pp. 509 - 512.

[12] KOURIL, K., CEP, R., JANASEK, A. KRIZ, A. STANCEKOVA, D. (2014). Surface integrity at reaming operation by MT3 head. In. Manufacturing Technology, Vol. 14, Issue 2, pp. 193 - 199.

[13]Czan, A., Sajgalik, M., Martikan, A., Mrazik, J. (2014). Observation of dynamic processes in cutting zone when machining nickel alloys. In. Komunikacie, Vol. 16/3A, pp. 161-168.

[14]KUMIČÁKOVÁ, D., GÓRSKI, F., MILECKI, A., GRAJEWSKI, D. (2013). Utilization of advanced simulation methods for solving of assembly processes automation partial tasks. In. Manufacturing Technology, Vol. 13, Issue 4, pp. 478 - 486.

[15]http://www.timplant.cz/cs/stomatolog/nanoimplant/ [cit. 2010-05-02]

[16]DANIŠOVÁ, N., RUŽAROVSKÝ, R., VELÍŠEK, K.(2011) Design alternatives of intelligent camera system for check parts at the intelligent manufacturing-assembly cell. In. ITMS 2011; Shanghai, Applied Mechanics and Materials, 7 Volume pp. 2262-2266

[17]CUBONOVA, N., KURIC, I. (2014). Data structures implementation of the protocol STEP-NC at CNC machines programming. In. Komunikacie, Vol. 16, Issue 3A, pp 176-183.

[18]GROTE, K.H., ANTONSSON, E.K. (2009). Handbook of Mechanical Engineering, Springer 2009/10, 1558 p

[19]BUDA, J., SOUČEK, J., VASILKO, K. (1983). Teória obrábania. Bratislava: ALFA, 1983. 392 p. 